\title{
Analysis of M-Learning Requirements in Arabic Language Learning
}

\author{
Hazrati Yahaya $^{1^{*}}$, Janudin Sardi, Mohammad Radzi, Ibrahim Youssef Abdelhamid², Kaseh Abu Bakar \& \\ Suhaila Zailani@Hj. Ahmad \\ 1.Akademi Pengajian Bahasa, Universiti Teknologi MARA (UiTM) 40450 Shah Alam, Selangor, Malaysia \\ 2.Fakulti Pengajian Islam, Universiti Kebangsaan Malaysia (UKM) 43600 Bangi, Selangor, Malaysia
}

\begin{abstract}
This article discusses the level of M-learning needed in Arabic language learning. This was a quantitative study using questionnaires as a research instrument for obtaining data. A total of 272 students were involved in this study. The method of analysis used was descriptive. The data obtained were analysed using the SPSS version 24.0 software to obtain percentage, mean, and standard deviation. The findings showed that respondents' perceptions of factors affecting the implementation of mobile learning and the level of readiness of mobile learning are at a high level. Hence, the concept of mobile learning is very useful in learning Arabic in this new era of learning. In addition, the findings showed that students had sufficient knowledge and awareness to use mobile technology in their educational environment. This study is very useful for those who want to develop mobile learning applications. Keywords: Needs analysis, Mobile learning, Arabic language, teaching and learning
\end{abstract}

DOI: $10.7176 / \mathrm{JEP} / 10-24-04$

Publication date: August 31st 2019

\section{Introduction}

The process of learning and accessing information has experienced rapid changes over the last decade. The ongoing global technology revolution has resulted in a shift from computing to the widespread use of mobile technology. The learning process is no longer dependent on traditional teaching methods, but has evolved by implementing technology in learning such as mobile learning. With that, mobile learning has become a new learning concept in this era that uses personal electronic devices assisted mobile technology as a learning medium and it is also it is also provides new and powerful opportunities for effective teaching and learning ( Serpil, 2017). Mobile learning (M-learning) is defined as the use of mobile technology to facilitate the learning process anywhere and anytime (Nail \& Ammar, 2017) and it can also be used to search for references. Furthermore it can be used to find useful information over a short period of time (Yulius Hari et al., 2016). M-learning can also be interpreted as an elearning pattern that presents learning support materials and educational content through wireless communication tools (Brown, 2005). Thus, it enables learning to occur without the need for certain physical infrastructures to achieve unlimited information. Some of the technologies or devices that can be used are personal digital assistant (PDA), smart handsets, iPads, iPods, tablets, personal computers (PCs), and so on. However smartphones and tablets are considered the most popular today (Fahad, 2018)

The effectiveness of M-learning in teaching and learning is undeniable and is evident through previous studies. The study conducted by Alkhezzi \& Al-Dousari, (2016) showed that the use of M-learning gives students an effective understanding of vocabulary and grammar. The results of the study by Normah et.al (2017) found that students were more fond and motivated to learn Arabic grammar with the help of WhatsApp applications than training in official lectures. Furthermore, Chen et al. (2013) emphasised that mobile platforms allow students to collaborate with their classmates in finding and sharing information. This suggests that smartphones can be easily used in any learning environment either inside or outside the classroom. Valtonen et al. (2011) used mobile devices with their students to enable them to collaborate and share lecture notes via Twitter. His students discussed class activities and exchanged information related to the course using this media platform. They stated that Twitter enabled them to interact and share information that affected the quality of learning. In addition, Alhazmi and Rahman (2013) believed that social media applications are able to create collaborative teams that actively promote student participation and engagement. A study on the development of Android-based mobile applications for learning Arabic vocabulary can provide a positive impact on students to memorise vocabulary in Arabic (Ramlah et al., 2016) In addition, Dony et al. (2018) developed an Arabic language learning app that offers a method of learning Arabic equipped with learning levels and appropriate exercises. The use of this app among consumers, especially children, has had a positive impact on Arabic language reading skills. This is because the app is equipped with multimedia elements such as graphics and audio that appeal to the child and successfully correspond to the lessons they are listening to.

However, the level of M-Learning usage in Malaysia is only moderate and it can be said that it is still a relatively new tool (Nur Atikah et al., 2016). While M-Learning is still at a moderate level, the use of M-Learning will be made compulsory for students and trainers due to certain factors. Among the factors are the widening, sophisticated, and inexpensive use of its technology and infrastructure. Therefore, in the effort to highlight this M- 
learning concept, this study was conducted to identify the level of respondents' perceptions on the factors affecting the implementation of mobile learning as well as the level of mobile learning readiness as a needs analysis for developing Arabic language mobile applications.

\section{Background of study}

Arabic is the national language for some Arab nations and it is a political, trustworthy, business, thought, and cultural language for Muslims around the world, with a ratioof 1 out of 5 of the world's population today speaking the language including Malaysia (Zainur Rizal \& Rosni Samah, 2007). Today's Arabic speakers have exceeded an estimated 422 million people worldwide (Ku Fatahiyah et al., 2014). Arabic is also developing as a world language in the global education sector. The establishment of units and institutions of study in countries other than Arab countries, such as America, Britain, including Malaysia, proves the acceptance of this language internationally (Wan Azura, 2006). Malaysia has also introduced Arabic language subjects at all levels of education including tertiary education. Arabic has been one of the elective courses in universities as well as a compulsory course in several faculties. As a result, the number of students studying Arabic at various levels has increased over time (Hanafi et al., 2017). However, this effort is considered futile when the students' mastery of the language is still quite weak (Al-Muslim \& Zamri Arifin, 2012).

In general, there are four essential skills in language teaching, namely listening, speaking, reading, and writing skills. Thus, the teaching of Arabic in Malaysia has placed the goal of enabling students to master the four language skills (Zawawi Ismail et al., 2011). However, students are still unable to acquire Arabic language proficiency and are not confident to use Arabic outside the classroom (Noor Anida et al., 2013). This condition may be due to the fact that students only learn Arabic to purely pass the exam. In addition, there are some other factors that make students' mastery of Arabic language skills still unproductive and this has become a concern among researchers in Malaysia (Shukri et al., 2009; Hayyi et al., 2012). Among the factors are the selection of teaching pedagogy that does not meet the needs of the students as well as the teaching objectives. This will have a negative impact on students in mastering the language. This is because teaching proficiency influences student performance (Maaike et al., 2019).

Effective teaching and learning can be produced if lecturers have innovative and creative qualities (Kamarul Azmi \& Ab. Halim, 2007). The teaching process will be easy and effective with the use of teaching aids. The presence of teaching aids in teaching and learning makes the task of instructors become easier and in turn can improve the effectiveness of learning. However, the effective use of teaching aids has not been fully implemented among teachers. Through the study of Ghazali et al., (2012) conducted on the use of teaching aids among MARA University of Technology (UiTM) instructors, it was shown that only the use of textbooks was at a high frequency, while other materials were at low frequency rates. As such, they rely on the use of textbooks solely to explain the content of learning.

The maximum dependence on textbooks in the classroom without involving the use of other teaching aids will cause students to become passive and reluctant in communicating in Arabic and also shy away from two-way communication. This will cause the learning process of Arabic language to be less encouraging. However, with the sophistication of technology that is growing rapidly day to day, the Arabic teaching and learning process also needs to evolve in tandem with current technological developments. This is in line with the demands of the $21^{\text {st }}$ century can make use of the different technology in teaching and learning. The use of technology is the basic catalyst in the daily life of the community including students and employees. One of the information technology tools that the society uses frequently are smartphones.

In general, smartphones are not limited to only one area but with the existence of borderless knowledge, smartphones can be applied in various branches of knowledge and this will provide convenience to those who wish to study. Indirectly, the learning process can be done anywhere and anytime, which is in line with the core development of Malaysia's Education Blueprint 2015-2025, which wants to bring life-long learning skills. But the question here is how far is the perception of students on the factors affecting the implementation of mobile learning and the level of mobile learning readiness in Arabic learning?

\section{Research Objective}

The study discussed in this paper is a preliminary study and is part of the study of Arabic language mobile application speech development. The design of the mobile application development study is based on ADDIE's instructional design model (Analysis, Design, Development, Implementation, and Evaluation). The ADDIE model consists of five important phases, namely the analysis phase, the design phase, the development phase, the implementation phase, and the evaluation phase. According to the ADDIE model, the first phase of the study is the requirement phase. In this phase, the items analysed are the respondents' level of perception to the factors that influence the implementation of mobile learning as well as the level of readiness of mobile learning in Arabic language learning. 


\section{Methodology}

In this study, the researchers selected a quantitative approach involving the use of questionnaires. Questionnaires were used to obtain information before the study of the Arabic language mobile application. In the analysis, the researchers used items with a a 5-point Likert scale, whereby (1) Strongly Disagree; (2) Disagree; (3) Not sure; (4) Agree, and (5) Strongly Agree. The use of the 5-point Likert scale can facilitate the understanding of students to answer the questionnaire so that they do not face misinterpretation problems in the questionnaire. The questionnaire for the research needs analysis was adapted from Kamaruzzaman's (2012) questionnaire and the modification was carried out to conform with the study's needs.

Questionnaire forms were divided into three sections. Part A is about respondents' background. Part B is to determine the level of respondents' perceptions on the factors that influence the implementation of mobile learning, while part $\mathrm{C}$ is the readiness of mobile learning for Arabic language learning. A pilot study was conducted first on 95 students at UiTM Shah Alam. The results of the pilot study found that the alpha Cronbach's value for the item was 0.81. According to Mohd Majid Konting (2005), a questionnaire can be used if the value of reliability coefficient exceeds 0.60 .

The respondents used for the study were UiTM Shah Alam undergraduates enrolled in level one Arabic course as a compulsory elective course. There were 272 students. The stratified random sampling technique was used to select students who took part in this research study. The sampling technique was chosen because UiTM students consisted of different clusters and academic centres. The data collected through the questionnaire were analysed using SPSS software version 24.0 to obtain percentage, mean. and standard deviation. The interpretation scale used for the min in this study is as follows:

Determination of Levels Based on Min Score

\begin{tabular}{|l|l|}
\hline Min Score & Interpretation \\
\hline 1.00 until 2.23 & Low \\
\hline 2.34 until 3.67 & Medium \\
\hline 3.68 until 5.00 & High \\
\hline
\end{tabular}

\section{Results and Finding}

Part A is the respondents' profile that consists of three items, namely cluster, gender, and those who have previously studied Arabic.

Table 1 Students' Demographic Background Information

\begin{tabular}{|l|l|l|l|}
\hline Item & Sub-item & Frequency (N) & Percentage (\%) \\
\hline \multirow{5}{*}{ Cluster } & Academic & 43 & 15.8 \\
\cline { 2 - 4 } & Social science & 68 & 25.0 \\
\cline { 2 - 4 } & Technology Science & 161 & 59.2 \\
\hline \multirow{3}{*}{ Gender } & Male & 94 & 34.6 \\
\cline { 2 - 4 } & Female & 178 & 65.4 \\
\hline \multirow{2}{*}{ Ever learned Arabic } & Yes & 173 & 63.6 \\
\cline { 2 - 4 } & No & 99 & 36.4 \\
\hline
\end{tabular}

Table 1 presents the demographic background of students participating in this study and there are a total of 272 students. From the cluster, there were $43(15.8 \%)$ students in academic clusters, while $68(25.0 \%)$ were in social science clusters and $162(59.2 \%)$ students in science. From the gender aspect, men comprised $94(34.6 \%)$ students and women were 178 (65.4\%). Respondents came from various Arabic backgrounds; 99 (36.4\%) students never studied Arabic before enrolling in UiTM, whereas 173 (63.6\%) students had studied Arabic in high school. Part B is the respondent's perception of the factors that influence the implementation of mobile learning.

Table 2 respondents' perceptions of factors affecting the implementation of mobile learning

\begin{tabular}{|l|l|l|l|}
\hline Code & Item & Min & SP \\
\hline B1 & $\begin{array}{l}\text { I like to try something new especially with regard to mobile } \\
\text { learning }\end{array}$ & 4.02 & 0.595 \\
\hline B2 & I have a high interest in mobile learning & 3.88 & 0.620 \\
\hline B3 & I do not want to miss out on a new method in mobile learning & 4.13 & 0.520 \\
\hline B4 & $\begin{array}{l}\text { I am always positive about the use of the latest technology in } \\
\text { learning }\end{array}$ & 4.10 & 0.535 \\
\hline B5 & Instructions from university administration & 3.61 & 0.741 \\
\hline B6 & Instructions and encouragement from the school & 3.67 & 0.720 \\
\hline B7 & Requirements in learning & 4.03 & 0.627 \\
\hline B8 & I have a deep knowledge of mobile learning & 3.50 & 0.773 \\
\hline
\end{tabular}

Table 2 shows the results of the analysis on questionnaires related to students' perceptions on factors affecting the implementation of mobile learning. Overall, the mean score for each construct exceeded 3.50 and above. This 
shows that students have a positive perception of readiness in the implementation of Arabic language learning. It was found that based on the mean score ,the item 'I did not want to miss using the new method in mobile learning' was the highest, at 4.13 followed by 'I was always positive about the use of the latest technology in learning' which scored 4.10. While the lowest mean score was the item, 'I have a deep knowledge of mobile learning'. Overall, the mean score for each construct exceeded 3.50 and this indicates that students have a positive perception of readiness in the implementation of Arabic language learning.

Part $\mathrm{C}$ is the readiness of mobile learning.

Table 3 mobile learning readiness

\begin{tabular}{|l|l|l|l|}
\hline Code & Item & Min & SP \\
\hline C1 & I know in depth about mobile learning. & 3.52 & .682 \\
\hline C2 & I would like to learn more about mobile learning. & 4.01 & .462 \\
\hline C3 & I prefer conventional learning rather than mobile learning. & 3.16 & .934 \\
\hline C4 & I do not mind paying extra money for mobile learning. & 3.03 & .794 \\
\hline C5 & Mobile learning will not make my life difficult. & 3.76 & .653 \\
\hline C6 & I'm ready for mobile learning if the university is implementing it now. & 3.86 & .593 \\
\hline C7 & $\begin{array}{l}\text { I want my lecturer to integrate mobile learning in my class apart from } \\
\text { the use of textbooks and Massive open online course (MOOC) }\end{array}$ & 3.91 & .656 \\
\hline C8 & Mobile learning will save my learning time. & 3.93 & .603 \\
\hline C9 & Mobile learning is an alternative to web-based learning. & 3.97 & .579 \\
\hline C10 & Mobile learning is an alternative to conventional learning. & 4.01 & .547 \\
\hline C11 & Some of my lecturers have integrated mobile learning in their teaching & 3.53 & .708 \\
\hline
\end{tabular}

Table 3 shows the study findings on the readiness of Arabic language learning. Overall, the mean score for the construct of the Arabic language mobile readiness level reached a simple and high level. A high mean score was recorded for items like, 'I would like to know more about mobile learning as well as 'mobile learning items is an alternative to conventional learning' which obtained a score of 4.01. Meanwhile the lowest mean score was, 'I do not mind paying extra money for mobile learning' at 3.03.

\section{Discussion}

The development of E-Learning in the teaching and learning process in educational institutions led to the introduction of a new educational technology, M-Learning. M-Learning is the evolution or continuity of ELearning learning concepts aimed at making the learning process more flexible and mobile (Aliff Nawi \& Mohd Isa Hamzah, 2013). Its feature as a user-friendly learning medium is seen as increasingly important as its more specific features are achievable anytime and anywhere. The practical curriculum makes it more attractive than traditional teaching and learning. Hence, M-Learning not only gives many benefits, but it is even seen as increasingly important in the education world today. The findings of the study showed that the level of respondents' perceptions on factors affecting the implementation of mobile learning and the level of mobile learning readiness are at a high level. In addition, the findings regarding the need for mobile Arabic learning among respondents also suggested that there is potential for developing mobile Arabic language applications. This situation coincides with several studies in the country such as studies by Ahmad Sobri (2010), Muhammad Ridhuan and Saedah (2010), and Mohd Aliff et al., (2011) which show that teaching and learning in the Arabic language also has the potential to be integrated with mobile technology.

\section{Conclusion}

This article discussed the findings of the analysis of mobile learning needs as part of the development of mobile applications for Arabic language learning. As discussed, past studies have shown that the use of smartphones as a learning medium has a positive impact as it can encourage students to become active in the learning process and indirectly help them to improve their achievement in the lesson. Through this positive study findings, it is proven that students are ready to use mobile learning as one of the new methods of learning.

\section{References}

Ahmad Sobri Shuib. (2010). Reka bentuk kurikulum M-Pembelajaran Sekolah Menengah: Teknik Delphi [Curriculum design of M-Learning Secondary School: Delphi Technique]. Proceedings of Regional Conference on Knowledge Integration in Information and Communication Technology, (pp. 652-665). Selangor: KUIS.

Alhazmi, A.K., Rahman, A.A. (2013). Facebook in higher education: students' use and perceptions. Adv. Inf. Sci. Service Sci, 15(5), 32-41.

Aliff Nawi \& Mohd Isa Hamzah. (2013). Tahap Penerimaan Penggunaan Telefon Bimbit Sebagai MPembelajaran Dalam Pendidikan Islam [Levels of Acceptance of Use of Mobile Phones as M-Learning in 
Islamic Education]. Journal of Islamic and Arabic Education, 5(1), 1-10.

Alkhezzi, F., \& Al-Dousari, W. (2016). The Impact of Mobile Learning on ESP Learners' Performance. The Journal of Educators Online-JEO, 2(13), 73-101.

Al-Muslim Mustapa \& Zamri Arifin. (2012). Pengajaran dan pembelajaran bahasa Arab: satu tinjauan literatur di Negeri Sembilan [Teaching and learning Arabic: a literature review in Negeri Sembilan]. Prosiding Persidangan Kebangsaan Pengajaran Dan Pembelajaran Bahasa Arab, (pp.15-33). Bangi: UKM.

Brown, T. H. (2005). Towards a model for m-learning ini Africa. International Journal On E-Learning, 4(3), 299315.

Chen, B., Seilhamer, R., Sugar, A., Jin, M., (2013). User acceptance of mobile technology: a campus-wide implementation of blackboard's mobile learn application. J. Educ. Comput. Res. 49 (3), 327-343.

Dony Rosadi, R. Arri Widyanto,S.Kom.,. Sunarni, (2018). rancang bangun aplikasi ayo belajar bahasa arab untuk anak usia dini berbasis android [design build application let's learn arabic language for android based early childhood]. Jurnal Komtika, 1(2), 29-37.

Fahad AlShareef, (2018), The Importance of Using Mobile Learning in Supporting Teaching and Learning of English Language in the Secondary Stage. Journal of Education and Practice, 15(9), 71-88.

Ghazali Yusri, Nik Mohd Rahimi, Parilah M. Shah, Muhammad Arsyad Abdul Majid dan Wan Haslina Wah. (2012), Penggunaan Bahan Pembelajaran dalam Kursus Bahasa Arab [Use of Learning Materials in Arabic Language Courses], GEMA Online ${ }^{\circledR}$ Journal of Language Studies, 12(1), 215-233.

Hanafi Dollah, Mohd Feham Md Ghalib, Muhammad Sabri bin Sahrir, Rusni Hassan, Abdul Wahab Zakaria, Zakaria Omar. (2017). Prototype Development of Mobile App for Trilingual Islamic Banking and Finance Glossary of Terms via iOS and Android Based Devices. International Journal of Interactive Mobile Technologies, 11(3), 145-161.

Kamarul Azmi Jasmi dan Ab. Halim Tamuri. (2007). Pendidikan Islam: Kaedah Pengajaran dan Pembelajaran [Islamic Education: Methods of Teaching and Learning].Cet. Ke-2. Skudai: Penerbit Universiti Teknologi Malaysia.

Ku Fatahiyah Ku Azizan, Awatif Abul Rahman \& Hairun Najuwah Jamali. (2014). Tahap Kemahiran Asas Bahasa Arab di Institut Pengajian Tinggi Malaysia [Level of Arabic Language Skills at the Malaysian Institute of Higher Education]. GSE E-Journal of Education, 2(1), 20-32

Maaike Koopman, Marieke Thurlings \& Perry den Brok. (2019). Factors influencing students' proficiency development in the fraction domain: the role of teacher cognitions and behaviour, Research Papers in Education, 34(1), 14-37.

Mohd Aliff Mohd Nawi, Surina Akmal Ab Sattai \& Mohd Isa Hamzaha. (2011). Kesediaan Penggunaan telefon bimbit sebagai M-Pembelajaran dalam kalangan guru Pendidikan Islam [Readiness for Using mobile phones as M-Learning among Islamic Education teachers]. Proceeding International Conference on World-Class Education. (pp.201-209).

Mohd. Majid Konting. (2005). Kaedah penyelidikan pendidikan [Methods of educational research] Kuala lumpur : Dewan Bahasa dan Pustaka.

Muhammad Ridhuan Tony Lim Abdullah \& Saedah Siraj. (2010). M-Learning curriculum design for secondary school: a needs analysis. World Academy of Science, Engineering and Technology International Journal of Educational and Pedagogical Sciences. 6(10), 1371-1376.

Nail B, Ammar WA (2017) Mobile Learning Education has Become More Accessible. Am J Compt Sci Inform Technol .5(2), 1-4. doi: 10.21767/2349-3917.100005

Noor Anida, Misrah Hamisah, Ruhaizan. (2013). Enhancing Arabic Speaking Skills among Malay Students through Group Work Activities, International Journal of Humanities and Social Science, 21(3), 212-219.

Normah Husin, Nor Azhan Norul 'Azmi, \& Mariam Mat Daud. (2017). Pembelajaran kolaboratif melalui aplikasi telefon pintar dalam pembelajaran nahu [Collaborative learning through a smartphone application in advanced learning], e-Jurnal Penyelidikan dan Inovasi, 1(4), 43-63.

Nur Atikah Jamilluddin, Mohd Jasmy Abd Rahman \& Nabila Atika Razali. (2017). Pengadaptasian " ELearning " Kepada " M- Learning " Dalam Teknologi Pendidikan ["E-Learning" Adaptation to "MLearning"in Educational Technology].Prosiding Seminar Pendidikan Serantau ke-VII.( pp. 572-580). Bangi.UKM.

Ramlah Basyir, Moch Kautsar Sophan, Rika Yunitarini. (2016). Rancang Bangun Aplikasi Android Media Pembelajaran Kosa Kata Bahasa Arab Bergambar dengan Menggunakan Model Pendekatan Addie [Designing the Android Media App Learning Arabic Vocabulary Learning Using the Addie Approach Model], Jurnal Ilmiah Edutic ,1(3).

Serpil Yorganci, (2017), Investigating Students' Self-Efficacy and Attitudes Towards the Use of Mobile Learning. Journal of Education and Practice, 6(8), 181-185.

Zakaria, N. Y. K., Zakaria, S. N., \& Azmi, N. E. (2018). Language Learning Strategies Used by Secondary Schools Students in Enhancing Speaking Skills. Creative Education, 9, 2357-2366. 
https://doi.org/10.4236/ce.2018.914176

Valtonen, T., Havu-Nuutinen, S., Dillon, P., Vesisenaho, M., (2011). Facilitating collaboration in lecture-based learning through shared notes using wireless. J. Comput. Assist. Learning. 27(6). 575-586.

Wan Azura Wan Ahmad. (2006). Pendekatan dan Strategi Efektif dalam Penguasaan Bahasa Arab [Effective Approaches and Strategies in Arabic Language Acquisition]. Nilai : Penerbit USIM.

Yulius Hari, Darmanto \& Minny Elisa Yanggah. (2016). Tingkat Adopsi Inovasi Teknologi Sistem M-Learning Dalam Pembelajaran Bahasa Mandarin Pada Tingkat SMA [Adoption Levels of M-Learning System Technology Innovation In Mandarin Language Learning At High School]. Prosiding Seminar Nasional Multi disiplin Ilmu \& Call For Papers Unisbank (sendi u).(pp.220-229).

Zainur Rijal Abdul Razak \& Rosni Samah. (2007). Kesan Bahasa Arab Dalam Peradaban Melayu Di Malaysia [Impact of Arabic Language in Malay Civilization In Malaysia]. Penerbit KUIM, Negeri Sembilan.

Zawawi Ismail, Ab Halim Tamuri, Nik Mohd Rahimi Nik Yusoff, Mohd Ala-Uddin Othman. (2011). Teknik Pengajaran Kemahiran Bertutur Bahasa Arab Di SMKA Di Malaysia [Arabic Language Teaching Techniques In SMKA In Malaysia]. GEMA Online ${ }^{\text {TM }}$ Journal of Language Studies, 11(2), 67-82. 